\title{
Microbial community of large freshwater lakes of the Eravno-Kharginskya lake system
}

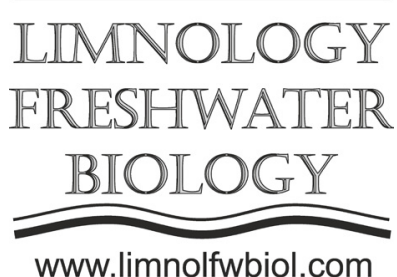

\author{
Dagurova O.P.*, Kozyreva L.P., Tsydenova B.V., Buryukhaev S.P., Zaitseva S.V., \\ Barkhutova D.D.
}

Institute of General and Experimental Biology, Siberian Branch of the Russian Academy of Sciences, Sakhyanovoi str., 6, Ulan-Ude, 670047, Russia

\begin{abstract}
The chemical and microbiological indicators of water were studied in the four large freshwater lakes of the Eravno-Kharginskaya lake system (Buryatia): Isinga, Gunda, Sosnovoe and Bolshoe Eravnoe. These lakes have great fishery and water management significance. The trophication of the lakes and the quality of their waters were evaluated. According to some indicators, the waters of the lakes belong to the oligotrophic type, according to some - to the mesotrophic type. The microbial community of studied lakes consists of bacterial phyla typical of freshwater ecosystems. The largest class of Gammaproteobacteria was characterized by a predominance of representatives of three genera: Acinetobacter (up to 35\%), Pseudomonas (up to 28\%) and Massilia (up to 17\%). Their predominance may indicate a possible change in the structure of the community under the influence of natural and anthropogenic factors. An increase in the proportion of the genus Exiguobacterium in the community and the detection of the genus Klebsiella in the lakes of Isinga and Gunda indicate the pollution of the lakes as a result of anthropogenic activity.
\end{abstract}

Keywords: freshwater lakes, microbial community, water quality, Eravno-Kharginskaya lake system

\section{Introduction}

Eravno-Kharginskaya lakes system has 10 large and more than 200 small lakes. They are located on the site of vast ancient lakes of the Mesozoic period. Most of these lakes are currently closed. Large lakes (Bolshoe and Maloe Eravnoe, Sosnovoe, Gunda, Isinga, Bolshaya Kharga) form the basis of the fisheries fund of the Republic of Buryatia (Plyusnin and Peryazeva, 2012; Bobkova and Sokolov, 2013). The Eravninsky lakes are relatively shallow, the average depths in most lakes do not exceed 3-4 m. The location of the lakes on the watershed elevation and the uneven precipitation regime determine the instability of their water regime. The study of the microbial communities of freshwater lakes in Buryatia and the identification of environmental factors affecting their formation and functioning have not been carried out before and therefore is relevant task.

\section{Materials and methods}

Samples of water for research were taken in July 2019 at 3 different sites of lakes Isinga, Gunda, Sosnovoye and Bolshoye Yeravnoye, from the surface horizon into sterile dishes. The chemical parameters of water were determined by classical titrimetric methods in a certified chemical laboratory and using portable instruments. The count of microorganisms was carried out by methods of classical microbiology. The identification of sanitary-indicative groups of bacteria (coliform bacteria and thermotolerant coliform bacteria) was carried out in accordance with MUK 4.2.1884-04 and GOST 24849-2014. Sequencing was carried out at the Center for Collective Use "Genomic Technologies, Proteomics and Cell Biology" of the AllRussian Research Institute of Agricultural Microbiology (VNIISKhM) in three technical replicates.

\section{Results and Discussion}

The water temperature during sampling was $21-26^{\circ} \mathrm{C}$, the total mineralization of the lakes varied from $276 \mathrm{mg} / \mathrm{l}$ (Isinga) to $380 \mathrm{~m} / 1$ (Sosnovoe), $\mathrm{pH}$ values - from 8.4 to 9.0 , the oxygen content was 8.6$12.2 \mathrm{mg} / \mathrm{l}$. The water of all the studied lakes belongs to the hydrocarbonate-sodium type. An increase in water salinity was found in comparison with previous studies (Plyusnin, Peryazeva, 2012). The high concentrations of organic matter (19 $-38 \mathrm{mg} / \mathrm{l})$ and the number of bacteria (1.03 - 3.3 million cells $/ \mathrm{ml})$ were revealed also. The highest values were recorded in Lake Sosnovoe. According to some indicators, such as oxygen content, transparency, the amount of production and 
destruction, the water of the lakes is of the oligotrophic type, but on mineralization, organic matter content, the number of bacteria there is the mesotrophic type. In lakes Sosnovoe and Bolshoe Eravnoe coliform bacteria and thermotolerant coliform bacteria were found in an amount of $60 \mathrm{CFU} / 100 \mathrm{ml}$. In lakes Isinga and Gunda the amount of coliform bacteria and thermotolerant coliform bacteria was higher - up to $200 \mathrm{CFU} / 100 \mathrm{ml}$. The sanitary and microbiological state of the lakes can be assessed as relatively safe. The waters of the lakes can be used for economic and recreational purposes.

Representatives of Proteobacteria (48-74\%), Actinobacteria (4-35\%) and Firmicutes (1.17-34.6\%) dominated in the microbial community of the studied lakes at the phylum level. Bacteroidetes (0.3-7\%), Cyanobacteria (0.9-6.5\%) and Planctomycetes (1.5$10.5 \%)$ were subdominants. The distribution of these phyla is typical for communities of freshwater lakes located in different geographic zones of the world (Newton et al., 2011). The most numerous class of Proteobacteria, Gammaproteobacteria, was characterized by the predominance of representatives of three genera: Acinetobacter (up to 35\%), Pseudomonas (up to 28\%), Massilia (up to 17\%). Acinetobacter have been found in metagenomes of various habitats, including soils and freshwater bodies with a high anthropogenic load (Lee et al., 2016). The genus Massilia, which also unites the genus Naxibacter, isolated from water, soil and air, is physiologically very versatile, it can use a wide range of organic substances. Representatives of this genus were previously found in the microbial community of the water of Lake Baikal (Bashenkhaeva et al., 2017).

Sequences of the genus Klebsiella were found in Isinga (up to $15.4 \%$ ) and Gunda (up to $28.1 \%$ ). Klebsiella is a genus of opportunistic bacteria that are widespread in environmental, including soil and water (Xu et al., 2010). They belong to the family Enterobacteriaceae, which are indicative of probable faecal contamination.

The maximum fraction of Firmicutes reached $34.6 \%$. Firmicutes are represented by the class Bacilli, the genus Exiguobacterium. The genus Exiguobacterium dominated in many samples. The genus Exiguobacterium has been found in habitats covering a wide range of temperatures and $\mathrm{pH}$. An increase in the proportion of the phylum Firmicutes, genus Exiguobacterium, was observed in the microbial community of the recreational polluted waters of freshwater lakes in the United States (Lee et al., 2016).

\section{Conclusion}

In the water of the studied lakes, an increase in water salinity, high concentrations of organic matter and the number of bacteria were found. The waters of the lakes can be used for economic and recreational purposes, however, the results obtained have revealed a tendency towards eutrophication, which may be associated with the lack of water in recent years and with economic activity.

The predominance of representatives of the genera Acinetobacter, Pseudomonas, and Massilia - may indicate a possible change in the structure of the community under the influence of natural and anthropogenic factors. An increase in the fraction of the genus Exiguobacterium in the community and the detection of enterobacteria of the genus Klebsiella in lakes Isinga and Gunda indicate the pollution of lakes as a result of anthropogenic pressure.

\section{Acknowledgments}

The work was supported by the Russian Foundation for Basic Research, project № 18-44030028 r_a, and partially within the framework of the State Assignment AAAA-A17-117011810034-9 for Institute of General and Experimental Biology, Siberian Branch, Russian Academy of Sciences.

\section{References}

Bashenkhaeva M.V., Zakharova Y.R., Galachyants Y.P. et al. 2017. Bacterial communities during the period of massive under-ice dinoflagellate development in Lake Baikal. Microbiology (Mikrobiologiya) 86(4): 524-532. DOI: 10.7868/S0026365617040036

Bobkova E.A., Sokolov A.V. 2013. Fishery usage of Eravno-Harginskaya lake system. Vestnik VSGUTU [Bulletin of the East Siberian State University of Technology and Management] 3: 168-172. (in Russian)

Lee C.S., Kim M., Lee C. et al. 2016. The microbiota of recreational freshwaters and the implications for environmental and public health. Frontiers in Microbiology 7. DOI: $10.3389 /$ fmicb. 2016.01826

Newton R.J., Jones S.E., Eiler A. et al. 2011. A guide to the natural history of freshwater lake bacteria. Microbiology and Molecular Biology Reviews 75: 14-49. DOI: 10.1128/ MMBR.00028-1

Plyusnin A.M., Peryazeva E.G. 2012. Hydrological and hydrochemical characteristics of the lakes in the Eravninskaya depression. Geografiya i Prirodnyye Resursy [Geography and Natural Resources] 33(2): 136-141. (in Russian)

Xu J., Li W., Chen X. et al. 2010. Klebsiella alba sp. nov., a novel pesticide-tolerant bacterium from a heavily polluted environment. Journal of General and Applied Microbiology 56: 241-247. DOI: 10.2323/jgam.56.241 